\title{
Wheat Breeding for Durable Rust Resistance and High Yield Potential in Historical Prospective and Current Status
}

\author{
Muhammad Hussain ${ }^{1, *}$, Muhammad Aslam Khan ${ }^{2}$, Yasir Ali ${ }^{2}$, Muhammad Makky Javaid ${ }^{3}$, \\ Babar Iqbal $^{1}$, Muhammad Nasir ${ }^{1}$, Waseem Sabir $^{3}$, Faqir Muhammad ${ }^{3}$ \\ ${ }^{1}$ Plant Pathology Research Institute, Ayub Agricultural Research Institute, Faisalabad, Pakistan \\ ${ }^{2}$ Department of Plant Pathology, University of Agriculture Faisalabad, Faisalabad, Pakistan \\ ${ }^{3}$ Wheat Research Institute, Ayub Agricultural Research Institute, Faisalabad, Pakistan
}

Copyright $\bigcirc 2017$ by authors, all rights reserved. Authors agree that this article remains permanently open access under the terms of the Creative Commons Attribution License 4.0 International License

\begin{abstract}
Epidemics of leaf, stripe and stem rusts on wheat have induced significant losses in the past during the early nineteenth century and have destroying role in reducing product yield bringing about socio-economic variability worldwide. The old tall varieties with qualitative resistance couldn't continue for longer period because of the advancement of new virulent pathogen races. But varieties like Yaqui-50, Lyalpur-73, and Lerma Rojo-64 were released during early period of green revolution, still linked with durable resistance to stripe, leaf and stem rust. Advancement of new rust races like virulence's $Y r 27$ and $Y r 9$ followed by the appearance of Ug99 and its mutants lead the breeders to review their breeding plan. Breeders are presently relying upon to gather minor genes and their use in grouping with major genes to develop rust resistance in wheat varieties. The minor genes, $L r 46 / Y r 29, L r 34 / Y r 18$, $\mathrm{Sr} 2 / \mathrm{Yr} 30$, are being broken in wheat breeding at CIMMYT and different region. The germplasm with this kind of resistance have shown existence stability over space and time. At Ayub Agriculture Research Institute, Faisalabad the home of green revolution in Pakistan, this approach has been established since1994-95. The durable resistance assortments were crossed in a top cross/back cross technique and the segregating populations were improved by adopting mass strategy, which brought about the advancement of material having preferred yield and rust resistance over the pre-exiting assortments (e.g., Inqlab-91, MH-97). Five varieties, Shafaq-06, Lasani-08, AARI-11, Millat-11 and Galaxy-13 from these crosses have been approved for general cultivation. Essentially, the material developed and circulated by CIMMYT, Mexico having this sort of resistance is being worldwide adopted. The simple sequence repeat markers (SSR) for above mentioned durable genes are accessible and can be used in early selection of superior varieties.
\end{abstract}

Keywords Breeding, Durable Resistance, Leaf Rust, Resistance Genes, Stem Rust, Stripe Rust, Wheat Varieties

\section{Introduction}

Wheat (Triticum aestivum L.) is the world's widely cultivated cereal crop along with maize and rice. The expected global wheat production for the year 2016 is 734.2 $\mathrm{Mt}$, which is slightly higher than the demand of $716.2 \mathrm{Mt}$ [11]. Global Wheat production has increased enormously since green revolution in 1960's and supported in reducing starvation and lack of healthy nutrition. Emerging nations, which expend sixty percent of total wheat production, have demonstrated higher yield increment contrasted with established nations in the past [59].

The three rusts, stripe, leaf or stem caused by $P$. striiformis, $P$. triticina and $P$. graminis f. sp. tritici, respectively, causing severe epidemics worldwide and therefore receive main attention in breeding program. The pathogen is very specialized having significant variant in their generation for virulence/avirulence against specific resistance genes. Emergence of different rust races via migration, mutation, and recombination between prevailing genotypes followed by selection is also common. Recent identification of new virulent Ug99 races such as PTKST, TTKSP, TTKSF, and TTKSF+ (http:/rusttracker.cimmyt.org/?page $\mathrm{id}=22$ ) and three highly virulent leaf rust races including FBPT, MCDS and $\mathrm{CCPS}^{41}$ present a significant threat to wheat production in South Africa, necessitating collaborative and integrated management approaches of the diseases.

Host-plant resistance against wheat diseases is the most appropriate, economically sustainable strategy to minimize yield losses contrasted to the application of crop protection 
fungicides [39]. Breeding strategy for durable rust resistance has always remained a dynamic practice [57]. Van der plank was first epidemiologist to openly describe the theoretical basis of the theories of resistance [60]. This strategy was commonly suggested for breeding against stripe rust resistance by Johnson [22], leaf rust resistance by Caldwell [7], and for stem rust resistance by Borlaug [6]. The use of such concepts in breeding against leaf rust resistance, generally known as slowly rusting, has been a leading force in CIMMYT wheat development structures for almost forty years with main impacts [32].

Diseases resistance can be generally classified as race specific or race non-specific. Race specific resistance controlled by major genes is frequently overcome by the emergence of new virulent races of the pathogen through sexual recombination or single step mutation [27, 58]. While race non-specific resistance also known as durable resistance controlled by minor gene, is long lasting. Thus advancement in breeding for durable resistance is slow, requiring identification and gene pyramiding into desirable varieties [4]. Screening for durable resistance genes need appropriate phenotyping to precisely identify their response in the field. Often varieties with durable resistance may show vulnerability at seedling stage but adult plants stage show low disease incidence. So it can be concluded that genetic improvement in wheat has generated at least twenty seven times its significance in benefits against leaf rust resistance breeding in spring wheat alone [32].

The main objectives of this study were to (1) access durable resistance against stripe, leaf and stem rust in selected wheat varieties through breeding strategies and (2) discuss a prospect of latent material maker strategy in wheat breeding.

\section{Breeding for Rust Resistance in Pre-green Revolution Era}

No serious effort was made in wheat development until the first half of the $19^{\text {th }}$ century. The traditional tall wheat varieties were normally known as landraces, which was selected through growers own choice of good seed for next season crop cultivation [10]. In Australia, Farrer proposed due thought for developing wheat rust resistant varieties. He mainly concerned on the early head to day maturity of varieties to escape rust and carefully selected the parents for hybridization work. To cross with Australian material early maturing germplasm was also imported from India. Back cross technique was used to produce rust resistance into Australian germplasm. A list including the different works of leaf wax presence, stomata size, and thickness of the cuticle and leaf width and rust resistance was prepared. These characteristics were remarkably like those one which are now considered as liable to decide durable disease resistance.

Interspecific crosses between wheat and Einkorn ( $T$. monococcum) were also developed for moving resistance in spring wheat. These crossing schemes were distant in India from 1896 to 1901 nevertheless couldn't adjust due to emergence of new land races. Few varieties belong to subcontinent i.e., India, Majhi, Bansi, Pissi, Bakhshi, Nagpur hybrid, was found somewhat moderately resistant and it demonstrated that these genotypes may contain some major resistant genes against rust resistance [16]. As an isolation of pure lines was the key breeding technique utilized for the advancement of wheat genotypes of land races at that time, so it can be concluded that these major genes were coevolved with the spring wheat. For introgression of alien alleles, breeding with collected developed and wild species from regions of primitive agriculture was likewise conducted in this part of the world. Their concern is clearly shown in wide crosses through the parents of prominent varieties Besostaja along with its wild species Kavkaz and Aurora.

In Germany, a few varieties like early winter wheat hybrid assortments, for example, Carstens 5 and Strube 56 were produced with a decent level of field resistance in 1934. It was felt that no further improvement was possible in the Indian subcontinent, hybridization and pure line selection was began for better assortments' established in 1926 [1]. In this manner, with the usage of exotic and local germplasm, a number of crosses were attempted. Varieties C-591, C-518, C-250, and 1C-217 were produced from these crosses. In all aspects, these varieties were better than prior stock. The assortment C-271 contains Lr34, a durable rust resistance gene. It has been shown that, this gene was used as a part of wheat breeding consciously [26]. So it can be summarized that, in the beginning of wheat breeding, while the information concerning the hereditary qualities of rust resistance was less advance, nevertheless main concern was proposed for the collection of assortments with improved good resistance.

\section{Breeding for Rust Resistance in the Green Revolution Era}

In CIMMYT, semi dwarf and dwarf varieties developed primary the Green Revolution (Pénjamo 62, and Sanora etc.) had been reliable for achievement performance in Pakistan, India, and elsewhere. The lifetime of the Mexican cultivars was short as the emergence of different races of black rust has completed its useful life; but, there are exceptions too. The Lerma Rojo 64 had 11 years lifetime, while Yaqui 50, 52 and 53 Champingo maintained their resistance until they were moved by cash crop of high yielding cultivars [6]. The long existence of these assortments is owing to inherited backgrounds. During time period 1965 to 1985 , the breeding technique has combined different CMMYT genes. A large portion of the cultivated genotypes through this era comprise Sr2 and 2-4 other genes for resistance to black rust (Table 1). These additional genes comprises $\mathrm{Sr} 36, \mathrm{Sr} 31, \mathrm{Sr} 30, \mathrm{Sr} 26$, Sr24, Sr17, Sr12, Sr11, Sr10, Sr9g, Sr9e, Sr9b, Sr8a, Sr7b, $\operatorname{Sr} 7 a, \operatorname{Sr} 6, \operatorname{Sr} 5$ [24, 43]. The similar approach was also implemented through the numerous national projects.

The significance of $\operatorname{Lr} 13$ to brown rust was accepted in the mid-1970s, when it was moved alongside other genes in numerous wheat cultivars. A few cultivars contain in mix 
Lr13 with other genes developed in Mexico, Pakistan and India is shown is Table 2. The Lrl3 itself could not give good resistance, although in combination with different genes that bears a high resistance level likely to be durable. The method for activity of Lrl3 complex program CIMMYT is a non-race particular sort of resistance. Their occurrence in grouping to $L r 34$ gene in particular fellows of the Bluebird sequences gave them a lengthy time. Lyalpur-73 variety is another illustration of this grouping in Pakistan that although substituted at farmer's field with the introduction of new high yielding, yet even following thirty six years of freedom, still has excessive resistance to brown rust (20MRMS) in trap nurseries.

The material developed in the mid -1960s had acquired resistance to yellow rust of the Andean regional varieties possessing a great resistance level. In Sudan, New Zealand, South Africa, and North Africa Anza was released resulting after cross of $\mathrm{LR} / \mathrm{N} 10 \mathrm{~B} / 3 * \mathrm{ANE}$. It was observed a durable resistance against stripe rust by Johnson ${ }^{22}$ and such type of response was also observed by Anderson [43]. According to Singhthe non-specific or durable resistance was concerned with the occurrence of $\operatorname{Yr} 18$ gene [56].

Table 1. Pedigree and Selection Histories of Wheat Varieties Possessing Stem Rust Resistant Genes

\begin{tabular}{|c|c|c|c|}
\hline Varieties & Parentage & Selection history & Resistant genes \\
\hline Bluesilver & $\begin{array}{c}\text { 1153.388/AN//YT54/N10B/3/LR/4/D4946.A.4. } \\
\text { 18.2.IY/Y53//3*Y50 }\end{array}$ & II18427.0PAK & - \\
\hline Hartog & $\mathrm{VCM} / / \mathrm{CNO} / 7 \mathrm{C} / 3 / \mathrm{KAL} / \mathrm{BB}$ & CM8399-D-4M-4Y-2M-2Y-0M-0AUS & $\operatorname{Sr} 2, \operatorname{Sr} 8 a, \operatorname{Sr} 9 g, \operatorname{Sr} 30$ \\
\hline Yecora 70 & $\mathrm{CNO} / / \mathrm{SN} 64 / \mathrm{KLRE} / 3 / 8156$ & II23584-26Y-2M-1Y-0M-0PAK & - \\
\hline Maxipak & Penjamo 62'S' x Gabo 55 & - & Sr17 \\
\hline Bluebird & $\mathrm{CNO} / / \mathrm{SN} 64 / \mathrm{KLRF} / 3 / 8156$ & II 23584 & $\operatorname{Sr} 2, \operatorname{Sr} 5, \operatorname{Sr} 6, \operatorname{Sr} 8 a$ \\
\hline Pavon F 76 & $\mathrm{VCM} / / \mathrm{CNO} / 7 \mathrm{C} / 3 / \mathrm{KAL} / \mathrm{BB}$ & $\begin{array}{l}\text { CM8399-D-4M-3Y-1M-1Y-1M-0Y-0 } \\
\text { MEX }\end{array}$ & $\operatorname{Sr} 2, \operatorname{Sr} 8 a, \operatorname{Sr} 12, \operatorname{Sr} 30$ \\
\hline Songlen & Lerma Rojo 64/Sonora64A/2/Timgalen & - & Sr2, Sr5, Sr6, Sr8a, Sr36 \\
\hline Selkirk & (McMurachy x Exchange) $x$ Redman & - & $\operatorname{Sr2,Sr6,Sr7b,Sr9d,Sr17}$ \\
\hline Hope & Marquis x emmer ("speltz") & - & $\operatorname{Sr} 2, \operatorname{Sr} 7 b, \operatorname{Sr} 9 d, \operatorname{Sr} 17$ \\
\hline LermaRojo 64 & $\mathrm{Y} 52 / \mathrm{N} 10 \mathrm{~B} / / \mathrm{L} 52 / 3 / 2 * \mathrm{LR}$ & II8724-8Y-1C-6Y-0MEX & $\operatorname{Sr} 2, \operatorname{Sr} 6, \operatorname{Sr} 7 b, S r 9 e$ \\
\hline Sunco & SUN9E-27*4/3Ag14//WW15/3/3*Cook & SUN88E & $\begin{array}{l}\text { Sr5, Sr6, Sr8a, Sr24, } \\
\text { Sr36 }\end{array}$ \\
\hline Kalyansona & PJ62/GB55 & II8156-0IND & - \\
\hline Sonalika & $\begin{array}{c}\text { 1153.388/AN//YT54/N10B/3/LR/4/BA4946.A. } \\
\text { 4.18.2.IY/Y53//3*Y50 }\end{array}$ & II18427-4R-1M-0IND & $\operatorname{Sr} 2$ \\
\hline
\end{tabular}

Table 2. Pedigree and Selection Histories of Wheat Varieties Possessing Leaf Rust Resistant Genes

\begin{tabular}{|c|c|c|c|}
\hline Varieties & Parentage & Selection histories & resistant genes \\
\hline Bluebird & $\mathrm{CNO} / / \mathrm{SN} 64 / \mathrm{KLRF} / 3 / 8156$ & II 23584 & $\operatorname{Lr1}, \operatorname{Lr} 13, \operatorname{Lr} 34$ \\
\hline Mexipak 65 & Penjamo 62'S' x Gabo 5 & - & $\operatorname{Lr} 14 a$ \\
\hline Ciano 79 & $\begin{array}{l}\text { BY/MAYA/4/BB//HD832.5.5/ON/3/CNO67/P } \\
\text { J62 }\end{array}$ & CM31678-R-4Y-2M-2122-OM-OMEX & Lr16 \\
\hline Lerma Rojo & $\mathrm{Y} 52 / \mathrm{N} 10 \mathrm{~B} / / \mathrm{L} 52 / 3 / 2 * \mathrm{LR}$ & II8724-8Y-1C-6Y-0MEX & Lr13, $\operatorname{Lr} 17$ \\
\hline Punjab 81 & INIA/3/SN64/P4160(E)// SN64 & - & $\operatorname{Lr10}, \operatorname{Lr} 13, \operatorname{Lr} 34$ \\
\hline Yecora 70 & $\mathrm{CNO} / / \mathrm{SN} 64 / \mathrm{KLRF} / 3 / 8156$ & II 23584 & - \\
\hline Sonora64 & YT54/N10B//2*Y54 & II8469-2Y-6C-2Y-1C-0MEX & Lrl \\
\hline Lyalpur 73 & $\mathrm{BB} / \mathrm{NOR}$ & II27100-307M-100A-0A-0PAK & $\operatorname{Lr1,Lr13,Lr34}$ \\
\hline Kalyansona & PJ62/GB55 & II8156-0IND & \\
\hline Sonalika & & & $\operatorname{Lr} 13, \operatorname{Lr} 14 a$ \\
\hline Bluesilver & $\begin{array}{c}1153.388 / \mathrm{AN} / / \mathrm{YT} 54 / \mathrm{N} 10 \mathrm{~B} / 3 / \mathrm{LR} / 4 / \mathrm{D} 4946 . \mathrm{A} .4 \\
.18 .2 . \mathrm{IY} / \mathrm{Y} 53 / / 3 * \mathrm{Y} 50\end{array}$ & II18427.0PAK & - \\
\hline Champingo 53 & - & - & Lr34 \\
\hline Pavon F 76 & $\mathrm{VCM} / / \mathrm{CNO} / 7 \mathrm{C} / 3 / \mathrm{KAL} / \mathrm{BB}$ & $\begin{array}{l}\text { CM8399-D-4M-3Y-1M-1Y-1M-0Y-0M } \\
\text { EX }\end{array}$ & $\operatorname{Lr1}, \operatorname{Lr} 10, \operatorname{Lr} 13, \operatorname{Lr} 46$ \\
\hline Nuri 70 & $\mathrm{CNO} / / \mathrm{SN} 64 / \mathrm{KLRE} / 3 / 8156$ & II23584-25Y-6M-0Y-0PAK & - \\
\hline Chines Spring & $\mathrm{CS} / \mathrm{CNO} . \mathrm{E} / / \mathrm{HORK} / 3 / \mathrm{CS} / \mathrm{CNO} . \mathrm{E} / 4 / 2 * \mathrm{CS}$ & CMH84.4449 & $\operatorname{Lr} 12, \operatorname{Lr} 34$ \\
\hline Dollarbird & WE-M/GTO//KAL/BB & CMA288-0AUS & - \\
\hline
\end{tabular}


Table 3. Pedigree and Selection Histories of Wheat Varieties Possessing Stripe Rust Resistant Genes

\begin{tabular}{|c|c|c|c|}
\hline Varieties & Parentage & Selection history & resistant genes \\
\hline Veery & $\mathrm{KVZ} / \mathrm{BUHO} / / \mathrm{KAL} / \mathrm{BB}$ & CM33027 & $\operatorname{Yr} 7, \operatorname{Yr} 9$ \\
\hline Lerma Rojo & $\mathrm{Y} 52 / \mathrm{N} 10 \mathrm{~B} / / \mathrm{L} 52 / 3 / 2 * \mathrm{LR}$ & II8724-8Y-1C-6Y-0MEX & Yra \\
\hline Lyalpur 73 & $\mathrm{BB} / \mathrm{NOR}$ & $\mathrm{WE}-\mathrm{M} / \mathrm{GTO} / / \mathrm{KAL} / \mathrm{BB}$ & $\operatorname{Yr} 18$ \\
\hline Champingo 53 & MARROQUI-588/NEWTHATCH & K-62053 & $\operatorname{Yr} 18$ \\
\hline Bluebird & $\mathrm{CNO} / / \mathrm{SN} 64 / \mathrm{KLRF} / 3 / 8156$ & II23584 & $\operatorname{Yr} 6, \operatorname{YrA}, \operatorname{Yr} 18$ \\
\hline Sonalika & $\begin{array}{c}1153.388 / \mathrm{AN} / \mathrm{YT} 54 / \mathrm{N} 10 \mathrm{~B} / 3 / \mathrm{LR} / 4 / \mathrm{BA} 4946 . \mathrm{A} \\
.4 .18 .2 . \mathrm{IY} / \mathrm{Y} 53 / / 3 * \mathrm{Y} 50\end{array}$ & II18427-4R-1M-0IND & $\operatorname{Yr} 2, \operatorname{Yr} A$ \\
\hline PBW343 (Attilla) & ND/VG9144//KAL/BB/3/YACO/4/VEE\#5 & CM85836-0IND & Yr Sulkirk (Yr 27) \\
\hline Ciano 79 & $\begin{array}{c}\text { BY/MAYA/4/BB//HD832.5.5/ON/3/CNO67/P } \\
\text { J62 }\end{array}$ & $\begin{array}{c}\text { CM31678-R-4Y-2M-21Y-0M-OM } \\
\text { EX }\end{array}$ & Yr Sulkirk (Yr 27) \\
\hline Pavon F 76 & $\mathrm{VCM} / / \mathrm{CNO} / 7 \mathrm{C} / 3 / \mathrm{KAL} / \mathrm{BB}$ & $\begin{array}{l}\text { CM8399-D-4M-3Y-1M-1Y-1M-0 } \\
\text { Y-0MEX }\end{array}$ & $\operatorname{Yr} 6, \operatorname{Yr} 7, \operatorname{Yr} 29$ \\
\hline Dollarbird & WE-M/GTO//KAL/BB & CMA288-0AUS & $\operatorname{Yr} 6, \operatorname{Yr} 7, \operatorname{Yr} 29^{*}$ \\
\hline Chines Spring & $\mathrm{CS} / \mathrm{CNO} . \mathrm{E} / / \mathrm{HORK} / 3 / \mathrm{CS} / \mathrm{CNO} . \mathrm{E} / 4 / 2 * \mathrm{CS}$ & CMH84.4449 & $\operatorname{Yr} 18$ \\
\hline Barani 83 & $\mathrm{BB} / \mathrm{GLI} / 3 / \mathrm{GTO} / 7 \mathrm{C} / / \mathrm{BB} / \mathrm{CNO}$ & $\begin{array}{l}\text { CM32347.3M-1Y-1M-1Y-1K-0A- } \\
\text { 0PAK }\end{array}$ & $Y r 7$ \\
\hline
\end{tabular}

During early decade of green revolution varieties released including $\mathrm{Yr} 18$ are given in Table (3). It has been reported in a number of cultivars e.g. Barani-83, PBW-12, WL-2265, Seri-82 (Yr9, Yr2, Yr7), Pavon-76 (Yr29, Yr7, Yr6), Pak-81 (YR9, Yr7) (Badebo et al. 1990). Pavon and Veery with $Y r 7$ gene had been released in various republics individually with various names which demonstrate the extensive use of Yr7genes.

\section{Emergence of New Rust Races}

Due to worldwide large scale dissemination of cultivars1B-1R translocation, monoculture condition created. This leads the development of different new races of rust causing devastating a severe wheat yield worldwide danger. A virulent strain of stripe rust, $Y r 9$ was first identified in North Africa during 1986 and then emigrated in South Asia. In 1991, it seemed in Yemen once to get to the wheat fields in South Asia it took only four years [52]. This caused great loss of performance on their way to Syria, Egypt, Turkey, Iraq, Iran, Pakistan and Afghanistan more than 1 billion US \$. Similarly $Y r 27$ appearance and development taking after the similar path that poses the main danger toward wheat generation in Pakistan and India, where super assortments Inqilab-91 and PBW343 were based resistance quality $Y r 27$. Varieties with stem rust resistance gene $\operatorname{Sr} 31$ remained effective more than thirty years. During 1990, wheat cultivars having1B-1R translocation made a situation of monoculture in Asia, Africa and different regions of the world. Pretorius [39] described that Pgt confines that were risky on Sr31 were gathered primary in Uganda during 1999 and after that extent all over East Africa, Kenya and Ethiopia in 2005. The race, known as TTKS (Ug99), is dangerous in maximum mega wheat cultivars and can bring about yield losses up to $100 \%$. Jin [21] identified another virulent race of Sr25 in India. This race is named as RRTTF as indicated by the American framework. Therefore, location of destructive races like $\operatorname{Sr} 25$ alarmed breeders to improve durable resistance in wheat varieties adopting advance breeding techniques.

\section{Genetic Basis of Durable Resistance}

Durable resistance to brown, stripe and stem rust depend on additive impact of genes typically control by minor genes. Genomic studied at CIMMYT Mexico revealed that, minimum ten to twelve different types of genes tangled in a collection of CIMMYT germplasm, and by collecting four to five race non-specific genes, resistance near immunity can be attained [57]. Singh described that line with two to three race non-specific resistance genes deliver a high level of resistance. Most of such type of genes are undersigned only Sr2/Yr30, Lr46/Yr29 and Lr34/Yr18 and identified on specific chromosomal loci [57].

The cultivars with race-nonspecific resistance gene show nearly similar level of resistance against different races of pathogen worldwide. However, the varieties that have the major gene endurance race specifically do not have a lengthy life and distorted generally after four to five years. The brown and stripe rust response of a few varieties with race non-specific rust resistance is the similar at CIMMYT, Mexico and Faisalabad, Pakistan (Table 4). Fontana being released fifty years ago up till now has good resistance practically everywhere. There exist very rare cases that varieties with race specific resistance have remained effective over a longer period of time. William identified six independent chromosomal loci contributing to durable resistance against leaf and stripe rust in population resulting from Avocet S and Pavon. Even Avocet S and Morocco have certain genomic characteristics that contain some durable resistance gene due to which critical delay occur to become fully susceptible [62]. Thus, estimation and use of genetic resources for rust resistance tangled both cultivated wheat measured worldwide and wild species. 
Table 4. Comparison of Leaf Rust Reaction of Varieties having Minor Gene Based Resistance in Maxico and Pakistan

\begin{tabular}{|c|c|c|c|}
\hline \multirow{2}{*}{ Variety/Line } & Minor Genes possessed Usual rust reactions & \multicolumn{2}{|c|}{ Usual rust reactions } \\
\cline { 2 - 4 } & & Mexico & Pakistan \\
\hline Nacozari 76 & Lr34+1 & $30 \mathrm{MSS}$ & $30 \mathrm{M}$ \\
\hline Sonoita & Lr34+1 & $20 \mathrm{MSS}$ & $10 \mathrm{M}$ \\
\hline Baconora 88 & Lr34+1 or $20 \mathrm{M}$ \\
\hline Frontana & Lr34+2 or 3 & $10 \mathrm{MSS}$ & $15 \mathrm{M}$ \\
\hline Trap\#1 & Lr34+2 or 3 & $10 \mathrm{MSS}$ & $20 \mathrm{M}$ \\
\hline Kukuna & Lr34+3 or 4 & $1 \mathrm{M}$ & $5 \mathrm{MR}$ \\
\hline Parula & Lr34+Lr46+1or $~$ & $10 \mathrm{MS}$ & $10 \mathrm{M}$ \\
\hline Pavon 76 & $L r 46+1$ & $30 \mathrm{MS}$ & $40 \mathrm{M}$ \\
\hline
\end{tabular}

Table 5. Potential Rust Reaction of Finally Selected Advance Lines of AARI, Faisalabad in Pakistan

\begin{tabular}{|c|c|c|c|c|c|}
\hline \multicolumn{2}{|c|}{ Leaf rust } & \multicolumn{2}{c|}{ Yellow rust } \\
\hline Genotype & Percentage & Bahawalpur & Faisalabad & Islamabad & Pirsabak \\
\hline $\begin{array}{c}\text { V-00183R } \\
\text { (shafaq-06) }\end{array}$ & V87094/2 Inq-91 & 0 & 0 & $10 \mathrm{MR}$ & $20 \mathrm{MR}$ \\
\hline V-02192 & SH88/V87094/MH97 & 0 & $20 \mathrm{M}$ & $10 \mathrm{R}$ & $5 \mathrm{RMR}$ \\
\hline V-02156 & SH-88/Weaver & $5 \mathrm{MR}$ & $40 \mathrm{M}$ & $10 \mathrm{RMR}$ & $20 \mathrm{RMR}$ \\
\hline V-7096 & Pb96/V87094/MH97 & $5 \mathrm{MRMS}$ & $30 \mathrm{MRMS}$ & $10 \mathrm{R}$ & $40 \mathrm{RMR}$ \\
\hline V-04179 & Pb96/V87094/MH97 & 0 & $40 \mathrm{M}$ & $10 \mathrm{R}$ & $40 \mathrm{RMR}$ \\
\hline V-03138 & Luan/koh.97 & $10 \mathrm{MR}$ & $30 \mathrm{M}$ & $5 \mathrm{R}$ & $15 \mathrm{MR}$ \\
\hline Mumtaz\#1 & LU26/PRL/LU26/TRAP & $10 \mathrm{MR}$ & $5 \mathrm{R}$ & $5 \mathrm{M}$ & $10 \mathrm{MR}$ \\
\hline Mumtaz\#2 & LU26/PRL/LU26/TRAP & $15 \mathrm{M}$ & $20 \mathrm{M}$ & $10 \mathrm{M}$ & $20 \mathrm{M}$ \\
\hline Morocco & & $100 \mathrm{~S}$ & $100 \mathrm{~S}$ & $100 \mathrm{~S}$ & $100 \mathrm{~S}$ \\
\hline
\end{tabular}

\section{Sr2/Yr30 Gene}

$\mathrm{Sr} 2$ gene was transferred from tetraploid emmer wheat variety Yaroslav to hexaploid wheat in 1920. It is located on chromosomal loci 3BS and pleiotropic to Lr27 [54]. It is linked with $\mathrm{Pbc}$ (pseudo black chaff) that is used as a morphological marker to identify lines that carry such type of gene. Pbc genotypes have shown variable degree of stem rust disease. The disease severity 60 to $70 \%$ was observed contrasted with $100 \%$ severity of susceptible control in nurseries, for detection of the disease in Kenya. This does not give an adequate level of resistance when present alone, but the desired level of resistance can be accomplished in association with different genes.

In $\mathrm{Sr} 2$ complex, a little bit information is known about the collaboration of $\mathrm{Sr} 2$ and other linked genes. Acceptable quality resistance can be attained by combining four to five minor genes $[25,28]$. Several cultivars of Kenya with $\mathrm{Sr} 2 / \mathrm{Yr} 30$ gene have been shown to be good source of durable resistance to stem rust $[3,33]$.

\section{Lr34/Yr18 Gene}

A large number of resistance genes to leaf and stripe rusts been recognized and are being used in breeding programs. Varieties such as Fontana with $L r 34$ gene have active durable resistance against leaf rust. $\operatorname{Lr} 34$ was first described in 1977 by Dyck, still provide the resistance against leaf rust and have been genetically indistinguishable from $\operatorname{Yr} 18$ gene giving adult plant resistance (APR) [36]. This gene is highly linked to leaf tip necrosis $(\operatorname{Ltn} 1)$, barley yellow dwarf virus $(B y d v 1)$ and powdery mildew resistance $(P m 38)$ genes [30].

If complex $\operatorname{Lr} 34 / Y r 18$ present, only the level of disease can go high, nonetheless in grouping with different genes could provide real management [31]. In greenhouse and growth chamber with low temperature resistance level of plants with $\operatorname{Lr} 34$ is too much higher. McIntosh [37] demonstrated that $L r 34$ appear to be dominant under natural conditions in daily normal temp $0-20{ }^{\circ} \mathrm{C}$ and aids in lessening disease development. Environment has a significant influence on the intensity of the terminal illness against leaf rust. Singh demonstrated that $\mathrm{Yr} 18$ can indicate inadequate resistance in some ecological circumstances [50].

In the current technique of getting new resistance to leaf rust assortments has developed from a selection of genes in individual pyramid of several genes, which could provide a durable resistance against different strains of wheat rust [29]. Genes for resistance against leaf rust about 60 have been distinguished in wheat and its wild species [48]. Qualitative Trait Loci (QTL) studies were used for genetic mapping for leaf rust in several populations [46]. 


\section{Lr46/Yr29 Gene}

Lr46 located on chromosomal loci 1B was identified in variety Pavon by crossing with leaf rust susceptible variety Lal Bahadur [56]. Its second minor gene providing durable resistance against leaf rust. The gene for resistance to stripe rust gene $Y r 29$ and $L r 46$ leaf rust are firmly connected with each other and characterized by its phenotypic maker leaf tip necrosis (Ltn2) [61]. Its impact is practically identical to Lr34/Yrl8 which provides incomplete resistance to crop.

Infested crops with such type of gene have length dormancy period contrasted with control without this genetic factor [34]. Crop containing such type gene also exhibit greater abortion rates fungal groups without chlorotic or necrotic impacts and furthermore lessen the measure of the spore size. Plants also do not show necrotic response to pathogen conferring such type of gene. The presence of Lr46/Yr29 is highly correlation with the plant leaf by showing leaf tip necrosis (Ltn2) [46]. Efforts are in progress for the colonization of this gene.

\section{Gene Pyramiding}

The process of incorporation of several genes in a single variety is required to develop a durable disease resistance cultivar. Most scientists in the world use this approach for three wheat rusts. Numerous gene pyramids have been effective, though some have immediately been rendered ineffective [47]. At least in a few cases, $\operatorname{Lr} 13$ and $L r 16$; and undesignated genes for yellow rust [13, 49] $L r 27$ and Lr31[54], Lr13 and Lr34 [9]; Lr2a and Lr16[12]; seem to have an additive impact in combination [33] Combination of some resistance gene, for example, the 'Sr2 complex' for stem rust resistance, the 'Frontana complex' for leaf rust resistance [44], a resistance of Little Joss and Anza assortments for stripe rust [22], have indicated long time stability. These complexes give the fundamental resistance in the developing bread wheat germplasm at CIMMYT. Such durable resistance can be consolidated with different qualities to provide diversity [45]. The breeding philosophy for creating quality pyramids includes the identification of hereditarily distinctive sources of resistance, followed by the combination of these resistances into a high yielding and improved background.

The resistance in at least 15 cultivars appeared to be due to Lr34 [50]. Several other cultivars with high seedling infection types to one or more of the predominant field prototypes were also partially resistant in the field [51]. High level of durable resistance occurred in some varieties even in the absence of known seedling resistance genes in major APR and slow rusting to brown rust have been reported in various cultivars of Mexican origin; Indian origin [88]; and other origins [44]. According to Rajaram (1972) adult plant resistance can be defined as resistance absent in seedlings, but expressed in the adult stage of the plant. Similarly, durable rust resistance may also be defined as a source that continued effective after the extensive development over a significant period [23].

\section{Combining Minor Genes for Durable Rust Resistance}

It's challenging task to accumulate race non-specific gene to achieve preferred level of resistance in the cultivars, because it need the pedigree of parentages having specific genes, crossing them with precise strategies proceeding back cross method preserving required population mass and collection of desirable varieties from isolating populations [55]. An example of breeding for incomplete or durable resistance is the outside CIMMYT wheat breeding program, Faisalabad, Pakistan. Under artificial inoculation the 1200 successions was selected with an assortment of leaf rust (TKT / RN, TKT / PR, JS/ KSR, PHTTL, PGRTB and stripe rust (80E85) races. The succession (Table 5) with durable resistance for stripe/leaf rust resistance was carefully screened [20]. For resistance and high yield the selected parents were crossed to accumulate minor genes for durable resistance.

The selected parentage was used to make top, back and double crosses. Bulk collection was done to progress the filial generations sustaining highest chromosomal diversity. With 0 to $20 \%$ disease severity and with MS/MR/R field response spikes were collected preferably at harvesting stage. Many advance lines were screened from this germplasm and established for rust reaction with high yield. From this germplasm two cultivars Lasani-08 and Shafaq-06 were allowed for broad cultivation in Punjab, Pakistan [17, 18]. These varieties showed high yield and rust resistance against stripe and leaf rust races such as $L r 26, L r 13, L r 10, L r 27, L r 9$. Lasani-08 was also evaluated against the race of stem rust (Ug99) in Kenya and Sindh, which showed acceptable resistance in 2007 [19].

\section{Conclusions}

The continuously varying nature of wheat stripe, leaf and stem rust pathogen have a major risk for prospect world wheat production. Learning from epidemic and losses due to emergence of rust races the researcher planned the approach of pyramiding durable resistance genes. The system of combining adult plant resistance genes was established by understanding rust resistance mechanism common in old semi-dwarf wheat varieties such as Lyalpur-73, Yaqui-50, and Lerma Rojo-64 which engaged resistance due to then unidentified durable resistance genes. Ayyub Agriculture Research Institute (AARI) and CIMMYT developed an approach of pyramiding durable resistance genes alone or in grouping with race specific genes to overcome the newly appeared strains of stripe, leaf, and black rust. Recent wheat varieties produced at AARI, Faisalabad, including Shafaq-06, Lasani-08, Millat-11, AARI-11 and Galaxy-13 are solid evidence of prospective durable adult plant resistance pyramiding approach to manage threats of stripe, leaf and stem rusts. 


\section{REFERENCES}

[1] M. A. Aziz. Cereals and Pulses. Resume of fifty years research work at Punjab Agricultural College and Research Institute, Lyallpur. Department of Agriculture West Pakistan. pp. 1960-1975, 1966.

[2] A. Badebo, R.W. Stubbs, M. Van-Ginkel, and G. Gebeyehu. Identification of resistant genes to Puccinia striiformis in seedlings of Ethiopian and CIMMYT bread wheat varieties and lines. Netherlands Journal of Plant Pathology. 96: 199-210, 1990.

[3] P. Bajgain, M. Rouse, T.J. Tsilo, G.K. Bhavani, Y. Jin, J.A. Anderson. Nested association mapping of stem rust resistance in wheat using genotyping by sequencing. PloS One. 11:0155760, 2016.

[4] U. Bansal, H. Bariana, D. Wong, M. Randhawa, T. Wicker, M. Hayden, B. Keller. Molecular mapping of an adult plant stem rust resistance gene Sr56 in winter wheat cultivar Arina. Theoretical and Applied Genetics. 127:1441-1448, 2014.

[5] N.E. Borlaug. The use of multilineal or composite varieties to control airborne epidemic diseases of self-pollinated crops. In: Proc 1st Inter Wheat Genet Symp, Univ. of Manitoba, Canada, pp. 12-27, (1958).

[6] N.E. Borlaug. Wheat breeding and its impact on world food supply In: 3rd Inter Wheat Genet Symp, F, H. (1982). Chemical and biological control of cereal mt. In K. J. Scott \& A.K. Chakravorty, eds. The rust fungi, p. 247-279. London, Academic Press, 1968.

[7] R.M. Caldwell. Breeding for general and/or specific plant disease resistance. In KW Findlay and KW, Shepherd (eds) Proc. 3rd Int. Wheat Genet Symp, Australian Academy of Science, Canberra, Australia, pp 263-272, 1968.

[8] P.L. Dyck. Genetics of leaf rust reaction in three introduction of common wheat. Canadian Journal of Genetics and Cytology. 19: 711-716, 1977.

[9] B. Ezzahiri, and A.P. Roelfs. Inheritance and expression of adult plant resistance to leaf rust in Era wheat. Plant Disease. 73: 549-551, 1989.

[10] D.F. Farrer. The making and improvement of wheats for Australian conditions. Agric. Gaz. N.S.W. 9: 131-167.FAO. 2016, 1898.

[11] What is conservation Agriculture? FAO, CAwebsite.(http://www.fao.org/ag/ca/la.html),

(2016). FAO,Rome.

[12] S.E. German, and J.A. Kolmer. Effect of Lr gene combinations on resistance to wheat leaf rust. Phytopathology. 79:1216, 1990.

[13] A. Grama, Z.K. Gerechter-Amitai, and C.H. Van Silthout. Additive gene action for resistance to Puccinia striiformis f. $\mathrm{sp}$. tritici in triticum dicoccoides. Euphytica. 33:281-287, 1984.

[14] S.A. Herrera-Foessel, E.S. Lagudah, J. Huerta-Espino, M.J. Hayden, H.S. Bariana, D. Singh, R.P. Singh. New slow-rusting leaf rust and stripe rust resistance genes Lr67 and Yr46 in wheat are pleiotropic or closely linked. Theoretical and
Applied Genetics. 122:239-249, 2011.

[15] S.A. Herrera-Foessel, R.P. Singh, J. Huerta-Espino, G.M. Rosewarne, S.K. Periyannan, L. Viccars, V. CalvoSalazar, C. Lan, E.S. Lagudah. Lr68: a new gene conferring slow rusting resistance to leaf rust in wheat. Theoretical and Applied Genetics. 124:1475-1486, 2012.

[16] A. Howard, and G.L.C. Howard. Wheat in India: Its Production, Varieties and Improvement. Calcutta: Thacker, Spink and Company, for the Imperial Department of Agriculture in India. pp.288, 1909.

[17] M. Hussain, A. Rehman, M. Hussain, F. Muhammad, M. Younis, A.Q. Malokra, and M. Zulkiffal. A new high yielding durable rust resistant variety Shafaq-06. Pakistan Journal of Phytopathology. 19:238-242, 2007.

[18] M. Hussain, M. Hussain, A. Rehman, F. Muhammad, M. Hussain, M. Zulkiffal, N. Ahmad, and M.A. Khan. Lasani-08, a new wheat variety with minor gene based rust resistance. Pakistan Journal of Phytopathology. 21: 152-158, 2009.

[19] M. Hussain, N. Ahmad, F. Muhammad, A. Rehman, M. Hussain, M.A. Khan, M. Hussain, and S. Ajmal. Wheat breeding for high yield potential and durable resistance against yellow rust. Pakistan Journal of Phytopathology. 21(1): 62-70, 2011

[20] M. Hussain, N. Ayub, S.M. Khan, M.A. Khan, F. Muhammad, and M. Hussain. Pyramiding rust resistance and high yield in bread wheat. Pakistan Journal of Phytopathology. 18:11-21, 2006.

[21] Y. Jin, L.J. Szabo, M.N. Rouse, T. Jr. Fetch, Z.A. Pretorius, R. Wanyera, and P. Njau. Detection of virulence to resistance gene Sr36 within the TTKS race lineage of Puccinia graminis f. sp. tritici. Plant Dis. 93:367-370, 2009.

[22] R. Johnson. Durable resistance to yellow (stripe) rust in wheat and its implications in plant breeding. In: Simmonds NW, Rajaram S (eds) Breeding strategies for resistance to the rust of wheat. CIMMYT, Mexico, D.F. pp63-75, 1988.

[23] R. Johnson, and C.L. Law. Genetic control of durable resistance to yellow rust (Puccinia striiformis) in the wheat cultivar hybrid de Borsee. Annals of Applied Biology. 81: 385-391, 1975.

[24] D. Knott. The inheritance of resistance to stem rust races 56 and 15B-1L (Can.) in the wheat varieties Hope and H-44. Canadian Journal of Genetics and Cytology. 10:311-320, 1968.

[25] D.R. Knott. Using polygenic resistance to breed for stem rust resistance in wheat. In: Breeding strategies for resistance to the rusts of wheat. (eds). CIMMYT, Mexico, pp. 39-47, 1988.

[26] J.A. Kolmer, X. Chen, and Y. Jin. Diseases which challenge global wheat production-the wheat rusts. In: Carver BF (ed) Wheat: science and trade. Wiley-Blackwell, IA, pp. 89-124, 2009.

[27] J. Kolmer, and M. Acevedo. Genetically divergent types of the wheat leaf fungus Puccinia triticina in Ethiopia, a center of tetraploid wheat diversity. Phytopathol. 106:380-385, 2016.

[28] J.A. Kolmer, E.S. Lagudah, M. Lillemo, M. Lin, G. Bai. The Lr46 gene conditions partial adult-plant resistance to stripe rust, stem rust, and powdery mildew in Thatcher wheat. Crop Sciences. 55:2557-2565, 2015. 
[29] Krattinger, S. G; Lagudah, E.S; Spielmeyer, W. (2009). Aputative $\mathrm{ABC}$ transporter confers durable resistance to multiple fungal pathogens in wheat. Crop Science. 323: 1360 1363.

[30] S. Liang, K. Savenaga, Z.H. He, W.L. Wang, H.Y. Liu, D.S. Wang, R.P. Singh, V. Sourdille, and Y.C. Xia. 2006. Quantitative trait loci mapping for adult plant resistance to powdery mildew in bread wheat. Phytopathology. 96:784-789.

[31] H. Ma, and R.P. Singh. Expression of adult resistance to stripe rust at different growth stages of wheat. Plant Disease. 80:375-379, 1996

[32] C.N. Marasas, M. Smale, R.P. Singh. The economic impact of productivity maintenance research: breeding for leaf rust resistance in modern wheat. Agricultural Economics. 29:253-263, 2003.

[33] R.A. McIntosh. 1988. The role of specific genes in breeding for durable stem rust resistance in wheat and triticale. In: Simmonds NW, Rajaram $S$ (eds) Breeding strategies for resistance to the rusts of wheat. CIMMYT, Mexico, D.F. pp1-9.

[34] F. Martinez, R.E. Niks, R.P. Singh, and D. Rubiales. Characterization of Lr46, a gene conferring partial resistance to wheat leaf rust Heredilas. Lund, Sweden. pp.135:111-114, 2001

[35] B.D. McCallum, C.W. Hiebert, S. Cloutier, G. Bakkeren, S.B. Rosa, D.G. Humphreys, G.F. Marias, C.A. McCartney, V. Panwar, C. Rampitsch, B.J. Saville, X. Wang. A review of wheat leaf rust research and the development of resistant cultivars in Canada. Canadian Journal of Plant Pathology. $38: 118,2016$.

[36] R.A. McIntosh. Close genetic linkage of genes conferring adult plant resistance to leaf rust and stripe rust in wheat. Plant Pathology. 41:523-527, 1992.

[37] R.A. McIntosh, C.R. Wellings, and R.F. Park. Wheat rusts: an atlas of resistance genes. CSIRO Publications, Melbourne, Australia, 1995.

[38] J. Onguso, P. Njau. Screening of Kenyan bread wheat varieties for resistance to the emerging strains of stem rust fungi (Puccinia graminis f. sp. tritici) race Ug99. World Journal of Agricultural Research. 3:5-10, 2015.

[39] Z.A. Pretorius, R.P. Singh, W.W. Wagoire, and T.S. Payne. Detection of virulence to wheat stem rust resistance gene Sr31 in Puccinia graminis f. sp. tritici in Uganda. Plant Disease. 84: 203, 2000 .

[40] Z. Pretorius, K. Pakendorf, G. Marais, R. Prins, J. Komen. Challenges for sustainable cereal rust control in South Africa. Crop Science Society of America. 58:593-601, 2007.

[41] Z. Pretorius, B. Visser, T. Terefe, L. Herselman, R. Prins, T. Soko, J. Siwale, B. Mutari, T.I. Selinga, D.P. Hodson. Races of Puccinia triticina detected on wheat in Zimbabwe, Zambia and Malawi and regional germplasm responses. Australian Plant Pathology. 44:217-224, 2015.

[42] S. Rajaram. Method for detection and evaluation of adult plant resistance to Puccinia graminis tritici in wheat. Proceedings of the European and Mediterranean Cereal Rusts Conference. Prah, Czechoslovakia. pp. 203-208, 1972.

[43] S. Rajaram, R.P. Singh, and E. Torres. Current approaches in breeding wheat for rust resistance. CIMMYT, Mexico D.F., Mexico. pp. 101-118, 1988.

[44] A.P. Roelfs, and J.V. Groth. Puccinia graminis f. sp. tritici, black stem rust of Triticum spp. In G.S. Sidhu, ed. Advances in plant pathology, vol. 6, Genetics of pathogenic fungi. London, Academic Press. pp. 345-361, 1989.

[45] A.P. Roelfs, R.P. Singh, and E.E. Saari. Rust diseases of wheat. Concepts and methods of disease management. Mexico, D.F: CIMMYT. pp. 81, 1992.

[46] G.M. Rosewarne, R.P. Singh, J. Huerta-Espino, and G.J. Robetzke. Quantitative trait loci for slow-rusting resistance in wheat to leaf rust and stripe rust identified with multi-environment analysis. Theoretical and Applied Genetics. 116:1027-1034, 2008.

[47] D.J. Samborski, and P.L. Dyck. Enhancement of resistance to Puccinia recondita by interactions of resistance genes in wheat. Canadian Journal of Plant pathology. 4:152-156, 1962.

[48] R.G. Saini, A.K. Gupta, and D. Anand. Factors influencing leaf rust resistance of some cultivars of wheat (Triticum aestivum L.). Journal of Plant Science and Research. 4:29-32, 1988.

[49] E.L. Sharp, and R.B. Volin. Additive genes in wheat conditioning resistance to stripe rust. Phytopathology. 60:1146-1147, 1970

[50] R.P. Singh. Genetic association of leaf rust resistance gene Lr34 with adult plant resistance to stripe rust in bread wheat. Phytopathology. 82:835-838, 1992.

[51] R.P Singh, and A.K. Gupta. Expression of wheat leaf rust resistance gene Lr34 in seedlings and adult plants. Plant Disease. 76:489-491, 1992.

[52] R.P. Singh, and J. Huerta-Espino. Global monitoring of wheat rusts and assessment of genetic diversity and vulnerability of popular cultivars. Research. Highlight of CIMMYT wheat program. CIMMYT, Mexico, 2000.

[53] R.P. Singh, and R.A. McIntosh. Complementary genes for resistance to Puccinia recondita tritici in Triticum aestivum L. Genetics and linkage studies. Canadian Journal of Genetics and Cytology. 26:723-735, 1984.

[54] R.P. Singh, and R.A. McIntosh. Genetics of resistance to Puccinia graminis tritici and Puccinia recondita tritici in Kenya Plume wheat. Euphytica. 35:245-256, 1984.

[55] R.P. Singh, and R. Trethewan. Breeding spring wheat for irrigated and rainfed 36. production systems of the developing world. In: Breeding major food staples: Kang M.S. and Priyadarshan P.M. (eds.) Blackwell Pub Ltd, UK, pp. 109-140, 2007.

[56] R.P. Singh, A. Mujeeb-Kazi, and J. Huerta-Espino. Lr46: a gene conferring slow rusting resistance to leaf rust in wheat. Phytopathology. 88(9):890-894, 1998.

[57] R.P. Singh, J. Huerta-Espino, and H.M. William. Genetics and breeding for durable resistance to leaf and stripe rusts in wheat. Turkish Journal of Agriculture. 29:121-127, 2005.

[58] T. Terefe, B. Visser, L. Herselman, T. Selinga, Z. Pretorius. First report of Puccinia triticina (leaf rust) race FBPT on wheat in South Africa. Australian Plant Pathology. 44:217, 2014. 
[59] F. Theodor, D. Roelf, and K. Amir. "Overview of the Global Spread of Conservation Agriculture ", Field Actions Science Reports [Online], Special Issue $6 \mid$ (2012), Online since 06 November 2012, connection on 29 March 2017. URL: http://factsreports.revues.org/1941.

[60] J.E. Vanderplank. Plant diseases: Epidemics and control. Academic Press, New York and London, 1963.
[61] H.M. William, R.P. Singh, J. Huerta-Espino, S. Ortiz-Islas, and D. Hoisington. Molecular Marker mapping of leaf rust resistance gene Lr46 and its association with stripe rust gene Yr29 in wheat. Phytopathology. 93: 153-159, 2003.

[62] H.W. William, R.P. Singh, and G. Palacios. Characterization of genetic loci conferring adult plant resistance to leaf rust and stripe rust in spring wheat. Genome 49:930-977, 2006. 